\title{
Control Strategies for Scabies
}

\author{
Daniel Engelman 1,2,3,4,* (iD) and Andrew C. Steer 1,2,3,4 \\ 1 Tropical Diseases, Murdoch Children's Research Institute, Parkville VIC 3052, Australia; \\ Andrew.Steer@rch.org.au \\ 2 Department of Paediatrics, University of Melbourne, Parkville VIC 3052, Australia \\ 3 Department of General Medicine, Royal Children's Hospital, Parkville VIC 3052, Australia \\ 4 International Alliance for the Control of Scabies, Parkville VIC 3052, Australia \\ * Correspondence: Daniel.Engelman@rch.org.au; Tel.: +613-9345-5522
}

Received: 12 August 2018; Accepted: 3 September 2018; Published: 5 September 2018

\begin{abstract}
Scabies is a neglected tropical disease of the skin, causing severe itching and stigmatizing skin lesions. Further, scabies leads to impetigo, severe bacterial infections, and post-infectious complications. Around 200 million people are affected, particularly among disadvantaged populations living in crowded conditions in tropical areas. After almost 50 years, research into scabies control has shown great promise, particularly in highly-endemic island settings, but these findings have not been widely adopted. Newer approaches, utilizing ivermectin-based mass drug administration, appear feasible and highly effective. Inclusion of scabies in the WHO portfolio of neglected tropical diseases in 2017 may facilitate renewed opportunities and momentum toward global control. However, further operational research is needed to develop evidence-based strategies for control in a range of settings, and monitor their impact. Several enabling factors are required for successful implementation, including availability of affordable drug supply. Integration with existing health programs may provide a cost-effective approach to control.
\end{abstract}

Keywords: scabies; neglected tropical diseases; impetigo; mass drug administration; ivermectin

\section{Introduction}

Scabies is a skin disease caused by infestation with the mite, Sarcoptes scabiei var. hominis. The female mite, measuring less than $0.5 \mathrm{~mm}$, burrows into the skin, where antigens on the exoskeleton of the mite, along with its saliva, excreta, and eggs, elicit a hypersensitivity reaction [1]. The resulting skin lesions most commonly affect the hands, wrists, ankles, and feet (Figure 1). In the vast majority of cases of common scabies (also known variably as ordinary, classical, or typical scabies) there is a low number of mites on the patient's body (5 to 15). Crusted scabies (formerly known as Norwegian scabies) is a rare form of the disease characterized by hyperinfestation with thousands to millions of mites and hyperkeratotic 'crusted' skin [2].

Transmission of scabies is predominantly via skin-to-skin contact. Transmission from bedding or clothes is rare in ordinary scabies, but can occur in crusted scabies because of its tremendous mite burden. The risk of transmission of scabies increases with higher levels of population density, reflected by the high endemicity observed in communities living in poverty with associated crowded housing conditions, and by outbreaks in in residential care facilities, prisons, schools, and refugee camps. Patients with underlying immunodeficiency from any cause, such as human immunodeficiency virus, human T-lymphotropic virus type 1 or corticosteroid treatment, or those with neurological conditions, are at an increased risk of crusted scabies [2-4].

Scabies causes considerable suffering due to the intense itch and associated scratching, leading to sleep disturbances which, in turn, impact on school and work attendance and performance, 
and ultimately the economic productivity of whole communities [5]. Like many infections that affect the skin, scabies is associated with social stigma and leads to social exclusion because of the appearance of the affected individual and attendant feelings of shame, as well as fears within the community of spread of infection [5,6]. Scabies can have a marked impact on quality of life measures, similar to the recognized psychological impact caused by other skin conditions such as psoriasis and vitiligo [7].



Figure 1. Infant with typical rash of scabies.

In endemic settings, scabies lesions are often super-infected with the bacteria Streptococcus pyogenes and Staphylococcus aureus. Bacterial infection occurs due to breaches in the skin barrier as a result of mite burrows and associated scratching [8], as well as direct effects of the scabies mite in downregulating host immunity and optimising conditions for bacterial growth $[9,10]$. These bacteria can cause local soft tissue infections such as impetigo, cellulitis, and abscesses, and can lead to life-threatening diseases including sepsis, and in the case of S.pyogenes, post-streptococcal glomerulonephritis [11], and possibly acute rheumatic fever (this link is epidemiologically associated but, as yet, unproven) [12,13].

This review aims to re-examine the rationale for public health control of scabies, evaluate the available evidence for scabies control interventions, and identify the barriers and future research priorities needed to develop and scale-up implementation of scabies control activities.

\section{Burden of Disease}

Scabies occurs worldwide, and is estimated to affect over 200 million people at any single time [14]. The highest prevalence of scabies occurs in tropical areas, especially in disadvantaged populations, and especially among children and the elderly. The Global Burden of Disease (GBD) study reported that scabies directly accounts for $0.21 \%$ of global disability-adjusted life years [15]. However, there are substantial gaps in our knowledge of the epidemiology of scabies and its complications.

First, many countries have no available data on scabies prevalence, including countries where disease burden is likely to be high, based upon known risk factors (poverty and overcrowding). For example, in a systematic review of prevalence studies of scabies published 1985 to 2015, only five sub-Saharan African countries were represented among the 48 studies included [16]. Where data do exist, they may be outdated and not representative of the current burden.

Second, routinely-collected data, and therefore GBD data, do not reflect actual disease burden. In countries where community-based prevalence survey data are available, the prevalence of scabies observed in these surveys is frequently substantially higher than the burden reported at the clinic level, and by the GBD study. For example, in the Solomon Islands, routine Ministry of Health clinic data identified 4759 cases of scabies in 2016 (total population of 584,000, corresponding to an incidence of $0.79 \%$ per year), in contrast to a detailed community-based survey in one province in the same year in which the prevalence was $19.2 \%$ [17]. This discrepancy may be because individuals within communities may not present with scabies (perhaps because it is 'normalized' or because effective treatments are often unavailable), or because there is under-diagnosis at clinics when patients do present [18]. 
Third, even when prevalence surveys are conducted, there is substantial heterogeneity in design and methods across studies. A key issue is the method used to diagnose scabies, which ranges from recovery of live mites by scraping of the skin, to a clinical diagnosis based on varying combinations of diagnostic features. This variability, noted even among scabies treatment trials [19], limits comparison of disease burden estimates across studies.

Fourth, there is limited evidence to determine the magnitude of the association between scabies and its complications. Available epidemiologic data suggest that, in highly endemic settings, at least $40 \%$ of impetigo lesions can be attributed to scabies, and an even higher proportion among younger children (71\% in one study) [17,20-22]. The high attributable risk observed in epidemiologic studies is supported by trials of community control of scabies, as outlined below, where impetigo prevalence has been shown to fall consistently and substantially with reductions in scabies prevalence.

\section{The Need for Surveillance and Control}

The World Health Organization Department of Neglected Tropical Disease (NTD) Control designated scabies as an NTD for large-scale disease control action in 2017. This designation was in recognition of: (1) the large known burden and impact of scabies, justifying a global response; (2) the geographic distribution of scabies among disadvantaged populations living in tropical and subtropical regions; (3) the amenability of scabies to public health control efforts, especially noting the success of mass drug administration (MDA) for scabies (detailed below); and (4) the broad neglect of scabies across multiple research domains [23]. In 2018, the ninth meeting of the WHO NTD Strategic Technical Advisory Group Global Working Group on Monitoring and Evaluation of NTDs recognized that there is a priority need to develop resources to aid defining the global burden of scabies, and to provide guidance for countries and regions for public health approaches for scabies control, including in outbreak situations [24].

Guidance is required for assessment of disease burden at local, national and regional levels, and should include guidelines for standardised diagnosis and surveillance methodology. Consensus criteria for the diagnosis of scabies were recently developed using a four-round Delphi process among 34 international experts, under the auspices of the International Alliance for the Control of Scabies (IACS) [25]. The IACS Criteria include three levels and eight subcategories such that the criteria can be applied across a range of situations, from a dermatologist's office to a field survey in a resource-limited setting (Table 1) [26].

Table 1. Summary of 2018 IACS $^{1}$ criteria for the diagnosis of scabies [26].

\begin{tabular}{|c|c|}
\hline Level & Criteria \\
\hline A. Confirmed scabies & $\begin{array}{l}\text { At least one of the following: } \\
\text { A1: Mites, eggs or faeces on light microscopy of skin samples } \\
\text { A2: Mites, eggs or faeces visualized on individual using high-powered imaging device } \\
\text { A3: Mite visualized on individual using dermoscopy }\end{array}$ \\
\hline B. Clinical scabies & $\begin{array}{l}\text { At least one of the following: } \\
\text { B1: Scabies burrows } \\
\text { B2: Typical lesions affecting male genitalia } \\
\text { B3 Typical lesions in a typical distribution and two history features }\end{array}$ \\
\hline C. Suspected scabies & $\begin{array}{l}\text { One of the following: } \\
\text { C1: Typical lesions in a typical distribution and one history feature } \\
\text { C2: Atypical lesions or atypical distribution and two history features }\end{array}$ \\
\hline History features & $\begin{array}{l}\text { H1: Itching } \\
\text { H2: Close contact with an individual who has itching or typical lesions in a typical distribution }\end{array}$ \\
\hline Notes: & $\begin{array}{l}\text { Diagnosis can be made at one of the three levels }(A, B, \text { or } C) \\
\text { A diagnosis of clinical or suspected scabies should only be made if differential diagnoses are considered } \\
\text { less likely than scabies. }\end{array}$ \\
\hline
\end{tabular}

${ }^{1}$ IACS: International Alliance for the Control of Scabies. 
The approach to community control for scabies is best aligned with the core strategies utilized by WHO Department of NTD Control: preventive chemotherapy using MDA, and/or innovative and intensified case management. Guidance around which approach to use will depend upon a number of factors, particularly disease burden at the community level. Therefore, feasible and accurate assessment of scabies prevalence will be crucial to inform an appropriate public health response, and also to monitor the effectiveness of this response. Below we outline the evidence to inform community control strategies for scabies, particularly MDA.

\section{Community Control}

The first reported public health initiatives to control scabies came from the San Blas islands (now known as the Guna Yala region) of Panama in the 1970s and 1980s. Scabies was introduced to the Guna populations and rapidly became endemic, with reported prevalences of $40-70 \%$ [27]. In a landmark series of studies, Taplin and colleagues compared approaches to scabies control in the islands. They found that treatment of all community members with $1 \%$ lindane resulted in a $98 \%$ cure rate at 10 weeks, whereas treatment of only those with clinically evident scabies had a lower effectiveness of $50 \%$ [28]. In areas where the entire community could not be treated, scabies was noted to return rapidly, leading the authors to conclude that, in those highly-endemic settings, 'treatment of individual patients without regard to community epidemiology is time consuming, and unlikely to have a significant impact in epidemic situations' [27]. Suspicion of developing mite resistance and the adverse effects profile of lindane then prompted the investigation of topical permethrin $5 \%$ for 756 residents on the island of Ticantiki. Following a MDA campaign with very high coverage, new arrivals to the island were treated and ongoing surveillance identified and treated new cases [27]. Scabies prevalence was reduced from $32 \%$ to below $2 \%$ and maintained for 3 years. Bacterial skin infection (impetigo) also declined from $32 \%$ to $1 \%$ in children without use of antibiotics. The permethrin-based MDA was well tolerated with few adverse events, but required a large project team for implementation. The team used directly observed applications, including to genital and breast areas, which may not be acceptable by some communities.

Drawing on the work in Panama, a control program commenced in five small, densely-populated islands in the Solomon Islands from 1997 to 2000 [29]. Use of topical treatments in this setting was considered 'so difficult as to be unacceptable and impractical'. Reports of the effectiveness of ivermectin for the individual and mass treatment of scabies [30], and knowledge of safety as a MDA strategy for lymphatic filariasis and onchocerciasis [31,32], led to selection of oral ivermectin as the main treatment, offered to the whole population as MDA. Permethrin $5 \%$ cream was given to children weighing less than $15 \mathrm{~kg}$ and pregnant women. Henceforth, we refer to this strategy of using topical treatments for ivermectin-contraindicated groups as 'ivermectin-based MDA'. Children (but not adults) were then re-examined at 6-monthly intervals and those with scabies and their household contacts were re-treated. Returned travelers and visitors were also treated, even if asymptomatic. No additional antibiotics were used. Over the three years of observation, the prevalence of scabies in children reduced from $25 \%$ to less than $1 \%$. The proportion of children with open sores, the median number of sores, and the proportion of children with microscopic hematuria also reduced significantly. In contrast to the Panama experience, where scabies resurgence was observed after disruption of permethrin supply, when 338 residents of the same communities in the Solomon Islands were examined for scabies more than 15 years later, only a single case of scabies was found [33].

An ecological study from northern Australia aimed to reduce scabies and secondary bacterial skin infection in five remote communities from 2004 to 2007 [34]. Permethrin 5\% was offered annually to all community members, but application was not directly observed. Children aged less than 15 years were screened regularly and referred for treatment if scabies or impetigo were identified. Whereas the prevalence of bacterial skin infection reduced during the project, there was little effect on scabies. A nested study found that actual use of permethrin was low, with only $44 \%$ of contacts applying the cream. Those households that did apply the cream had a much lower rate of scabies transmission [35]. 
The first controlled study of MDA for scabies control was conducted in Fiji in 2012. Three small island groups were randomized to one of ivermectin-based MDA (with permethrin for contraindicated groups), permethrin-based MDA, or 'standard-care' (where all community members were screened and referred for treatment if diagnosed with scabies). The trial found that at 12 months after MDA, the prevalence of scabies reduced in the ivermectin group by $94 \%$ (from $32 \%$ to $2 \%$ ), in the permethrin group by $62 \%$ ( $42 \%$ to $16 \%$ ) and in the standard-care group by $49 \%$ (37\% to $19 \%)$. Once again, a considerable reduction was observed in the prevalence of impetigo without additional use of antibiotic therapy, most notably in the ivermectin group, where impetigo prevalence fell by $67 \%$ ( $25 \%$ to $8 \%$ ).

Similar results were seen in two recent studies in the Solomon Islands. A before-and-after study evaluated a single round of ivermectin-based MDA, offered to a population of 26,000 , in combination with azithromycin MDA for trachoma control. The co-administration was well tolerated with no serious adverse events [36]. A smaller study, from a different region of the Solomon Islands, reported a reduction in scabies prevalence of greater than $90 \%, 12$ months after ivermectin-based MDA [37].

However, in a single cohort study in a remote island community of Australia, ivermectin-based MDA was less effective. Two MDA campaigns were implemented, 12 months apart, for a population of approximately 1000 . Scabies prevalence fell from a baseline of $4 \%$ to less than $1 \%, 6$ months after MDA, then increased to $9 \%$ after 12 months. A second MDA was conducted at this time, and scabies prevalence fell to $2 \%$ when measured 6 months later. Factors identified that may have contributed to the results included a lower than anticipated baseline prevalence, a highly mobile population with many new arrivals to the community after the first MDA, and a cluster of new cases associated with a case of crusted scabies.

Ivermectin-MDA programs for other NTDs also provide opportunities to study the effect on scabies [38]. In Zanzibar, Tanzania, annual MDA with ivermectin and albendazole for lymphatic filariasis from 2001-2005 resulted in a 68-98\% reduction in clinic presentations for scabies [39]. However, in a recent, prospective study from the Kongwa District of Tanzania, where the baseline prevalence of scabies was $4.4 \%$, annual ivermectin MDA for lymphatic filariasis was associated with a smaller reduction in scabies prevalence, to $2.9 \%$ after 4 years [40]. The authors concluded that a greater effect on scabies prevalence may not have been observed because of the relatively low prevalence and because only a single dose was given.

In addition to these community control strategies, there is increasing evidence of the use of MDA for management of scabies outbreaks within closed institutions such as schools, prisons, hospitals, aged care facilities and refugee and displaced person camps [30,41-43]. Scabies outbreaks in these settings are often difficult to diagnose and manage [44-46]. Ivermectin-based MDA has also been employed in the control of large-scale, open outbreaks, such as the current, drought-associated epidemic in Ethiopia, where more than one million people have been affected, although evaluation of this public health intervention is not currently available [47].

\section{Outstanding Issues}

The combined evidence of these control strategies reveals several common themes. First, in contrast to treating individuals and contacts, MDA strategies appear highly effective in reducing the burden of both scabies and impetigo. This strategy has been particularly successful in island communities with a very high baseline prevalence. With adequate community consultation, ivermectin-based MDA has been widely accepted by communities, well tolerated by individuals, and appeared more effective than permethrin-based MDA. Second, the benefit of MDA in communities with a lower baseline prevalence is less clear, and suggests that a different strategy may be appropriate for communities with lower prevalence (for example, less than 5\%). Third, the most effective strategies have been those where active surveillance and treatment of new cases and new arrivals to the community have been incorporated, but it remains unclear to what extent these additional measures are required to ensure sustainable program success. Finally, environmental control measures (such as the washing of linen and clothing, or insecticide spraying) have not formed a component of the 
most successful strategies, suggesting this labor-intensive and costly strategy may not be required for community control. For control of institutional outbreaks, particularly where individuals have crusted scabies, environmental measures, if feasible, may be warranted.

Despite the promise of studies on community control for scabies, there remain several important operational questions about how their findings should be implemented, and the expected impact of such interventions. As noted, MDA appears less successful in lower-prevalence settings, and it is not clear what prevalence of scabies, or other measure, should trigger consideration of MDA. Further investigation is required to determine the optimal strategy for MDA. It is unclear whether one dose of ivermectin per MDA round is sufficient, or whether a second dose is required after 7-14 days, as is clinically recommended when using ivermectin for individual case treatment, due to its inability to kill the mite eggs [48]. The number and frequency of MDA rounds, when to stop, and duration of surveillance after stopping are all unknown. Modelling research could play an important role in this area, as for other NTDs [49-51]. The treatment of young children and pregnant women is critical for reducing transmission because these groups harbor a disproportionate burden of disease. However, because of current limitations on ivermectin use, they can only receive topical treatments, which are less practical. There is some evidence that ivermectin may be safe in these groups [52,53], but definitive research and development of pediatric-friendly formulations are needed. Further work on the feasibility and acceptability of MDA programs by communities in various settings is also required.

Standardized methods for diagnosis and mapping are required, possibly building on the 2018 IACS criteria, which need validation and testing in a variety of settings [26]. Investment into basic scientific research is required, including the development of diagnostic tests, ideally point of care tests for low-resource settings [54,55]. In lower-prevalence settings, or where MDA may be unrequired or infeasible, different strategies need to be developed and evaluated, including mass treatment of high-risk groups, or enhanced surveillance and intensified case management. Simplified, integrated clinical care pathways [56,57], and strategies such as teledermatology [58-60] may have an important role in providing high quality care to remote areas. Distinct strategies are also required for closed outbreaks in both developed and resource-limited settings. Although MDA programs do not place huge selective pressures on the microorganisms they target, ongoing monitoring for potential mite resistance to ivermectin and topical agents is important [61-64].

The impacts of scabies control programs need further evaluation, as this will inform policy makers and stakeholders of the likely health and economic benefits of the program. In particular, understanding the impact of reducing scabies and impetigo on improving quality of life and reducing downstream health complications such as skin and soft tissue infections, sepsis, and rheumatic heart disease [25]. Understanding these outcomes will facilitate cost-effectiveness evaluations in a range of settings. Research into the understanding and conception of scabies and impetigo within communities, followed by community awareness and engagement strategies, will be crucial for programmatic success.

While MDA with ivermectin appears highly effective, there are disadvantages to its use, including the apparent need for two doses, as outlined above. Moxidectin is an oral compound related to ivermectin, and was recently approved by the United States Food and Drug Administration for treatment of onchocerciasis [65]. Moxidectin has a much longer half-life than ivermectin, spanning the entire life cycle of the scabies mite [66,67]. In a preclinical treatment study using a porcine model for scabies, a single dose of moxidectin was more effective than two doses of ivermectin [68]. Clinical studies in humans are now planned, with a view to developing moxidectin as a single-dose treatment for scabies $[67,69]$. If clinical development is successful, moxidectin would be a very attractive option for community control of scabies because it would obviate the need for a second dose and reduce the risk of early re-infestation. Alternative topical treatments may also be required if resistance to permethrin becomes problematic [64,70]. 
Finally, scabies control should not occur in a vacuum. There are a number of opportunities for integration of scabies control with other NTDs, especially around the use of ivermectin [71,72]. Examples include successful co-mapping of scabies prevalence with other NTDs $[17,73]$, and co-administration of ivermectin and azithromycin MDA with evaluation of multiple endpoints [36,37]. The roll-out of triple therapy (ivermectin, diethylcarbamazine, and albendazole) for the control of lymphatic filariasis [74,75] presents further opportunities to integrate evaluation of impact of this strategy on scabies.

\section{Conclusions}

In 2018, WHO recognized the need for 'a global strategy for scabies control' [24]. Such a strategy would align with the United Nations Sustainable Development Goals, including Target 3.3 to end the epidemic of NTDs (among other diseases) by 2030 [76]. Community control will be a central component of such a strategy, but broader progress will require consideration of several interrelated issues, including: engagement with key stakeholders at national, regional, and global levels to develop a coordinated, international framework; integration with existing NTD programs to leverage efficiency and cost-effectiveness of scabies control; provision of guidelines for monitoring and evaluation of programs; securement of drug supply at large scale; development of funding partnerships; and advancement of a research agenda, including operational research as outlined above, and research into improved diagnostics, new treatments (including moxidectin), and mite resistance monitoring.

Author Contributions: Conceptualization, D.E.; Writing-Original Draft Preparation, D.E. and A.C.S.; Writing-Review and Editing, D.E. and A.C.S.

Funding: This research received no external funding.

Acknowledgments: We acknowledge the contribution of Myra Hardy. The clinical photograph is provided courtesy of Daniel Mason. Informed consent was obtained and confidentiality maintained in accordance with the ethical review committee requirements.

Conflicts of Interest: The authors declare no conflict of interest.

\section{References}

1. Hay, R.J.; Steer, A.C.; Engelman, D.; Walton, S. Scabies in the developing world-Its prevalence, complications, and management. Clin. Microbiol. Infect. 2012, 18, 313-323. [CrossRef] [PubMed]

2. Chosidow, O. Clinical practices. Scabies. New Engl. J. Med. 2006, 354, 1718-1727. [CrossRef] [PubMed]

3. Davis, J.S.; McGloughlin, S.; Tong, S.Y.; Walton, S.F.; Currie, B.J. A novel clinical grading scale to guide the management of crusted scabies. PLoS Negl. Trop. Dis. 2013, 7, e2387. [CrossRef] [PubMed]

4. Walton, S.F.; Beroukas, D.; Roberts-Thomson, P.; Currie, B.J. New insights into disease pathogenesis in crusted (Norwegian) scabies: The skin immune response in crusted scabies. Br. J. Dermatol. 2008, 158, 1247-1255. [CrossRef] [PubMed]

5. Worth, C.; Heukelbach, J.; Fengler, G.; Walter, B.; Lisenfeld, O.; Feldmeier, H. Impaired quality of life in adults and children with scabies from an impoverished community in Brazil. Int. J. Dermatol. 2012, 51, 275-282. [CrossRef] [PubMed]

6. Hofstraat, K.; van Brakel, W.H. Social stigma towards neglected tropical diseases: A systematic review. Int. Health 2016, 8 (Suppl. 1), i53-i70. [CrossRef]

7. Olsen, J.R.; Gallacher, J.; Finlay, A.Y.; Piguet, V.; Francis, N.A. Quality of life impact of childhood skin conditions measured using the Children's Dermatology Life Quality Index (CDLQI): A meta-analysis. Br. J. Dermatol. 2016, 174, 853-861. [CrossRef] [PubMed]

8. Steer, A.C.; Jenney, A.W.; Kado, J.; Batzloff, M.R.; La Vincente, S.; Waqatakirewa, L.; Mulholland, E.K.; Carapetis, J.R. High burden of impetigo and scabies in a tropical country. PLoS Negl. Trop. Dis. 2009, 3, e467. [CrossRef] [PubMed] 
9. Swe, P.M.; Zakrzewski, M.; Kelly, A.; Krause, L.; Fischer, K. Scabies mites alter the skin microbiome and promote growth of opportunistic pathogens in a porcine model. PLoS Negl. Trop. Dis. 2014, 8, e2897. [CrossRef] [PubMed]

10. Swe, P.M.; Fischer, K. A scabies mite serpin interferes with complement-mediated neutrophil functions and promotes staphylococcal growth. PLoS Negl. Trop. Dis. 2014, 8, e2928. [CrossRef] [PubMed]

11. Hay, R.J.; Steer, A.C.; Chosidow, O.; Currie, B.J. Scabies: A suitable case for a global control initiative. Curr. Opin. Infect. Dis. 2013, 26, 107-109. [CrossRef] [PubMed]

12. Parks, T.; Smeesters, P.R.; Steer, A.C. Streptococcal skin infection and rheumatic heart disease. Curr. Opin. Infect. Dis. 2012, 25, 145-153. [CrossRef] [PubMed]

13. Thornley, S.; Marshall, R.; Jarrett, P.; Sundborn, G.; Reynolds, E.; Schofield, G. Scabies is strongly associated with acute rheumatic fever in a cohort study of Auckland children. J. Paediatr. Child Health 2018, 54, 625-632. [CrossRef] [PubMed]

14. GBD 2015 Disease and Injury Incidence and Prevalence Collaborators. Global, regional, and national incidence, prevalence, and years lived with disability for 310 diseases and injuries, 1990-2015: A systematic analysis for the Global Burden of Disease Study 2015. Lancet 2016, 388, 1545-1602. [CrossRef]

15. Karimkhani, C.; Colombara, D.V.; Drucker, A.M.; Norton, S.A.; Hay, R.; Engelman, D.; Steer, A.; Whitfeld, M.; Naghavi, M.; Dellavalle, R.P. The global burden of scabies: A cross-sectional analysis from the Global Burden of Disease Study 2015. Lancet Infect. Dis. 2017, 17, 1247-1254. [CrossRef]

16. Romani, L.; Steer, A.C.; Whitfeld, M.J.; Kaldor, J.M. Prevalence of scabies and impetigo worldwide: A systematic review. Lancet Infect. Dis. 2015, 15, 960-967. [CrossRef]

17. Mason, D.S.; Marks, M.; Sokana, O.; Solomon, A.W.; Mabey, D.C.; Romani, L.; Kaldor, J.; Steer, A.C.; Engelman, D. The prevalence of scabies and impetigo in the solomon islands: A population-based survey. PLoS Negl. Trop. Dis. 2016, 10, e0004803. [CrossRef] [PubMed]

18. Yeoh, D.K.; Anderson, A.; Cleland, G.; Bowen, A.C. Are scabies and impetigo 'normalised'? A cross-sectional comparative study of hospitalised children in northern Australia assessing clinical recognition and treatment of skin infections. PLoS Negl. Trop. Dis. 2017, 11, e0005726. [CrossRef] [PubMed]

19. Thompson, M.J.; Engelman, D.; Gholam, K.; Fuller, L.C.; Steer, A.C. Systematic review of the diagnosis of scabies in therapeutic trials. Clin. Exp. Dermatol. 2017, 42, 481-487. [CrossRef] [PubMed]

20. Romani, L.; Whitfeld, M.J.; Koroivueta, J.; Kama, M.; Wand, H.; Tikoduadua, L.; Tuicakau, M.; Koroi, A.; Ritova, R.; Andrews, R.; et al. The epidemiology of scabies and impetigo in relation to demographic and residential characteristics: Baseline findings from the Skin Health Intervention Fiji Trial. Am. J. Trop. Med. Hyg. 2017, 97, 845-850. [CrossRef] [PubMed]

21. Romani, L.; Koroivueta, J.; Steer, A.C.; Kama, M.; Kaldor, J.M.; Wand, H.; Hamid, M.; Whitfeld, M.J. Scabies and impetigo prevalence and risk factors in Fiji: A national survey. PLoS Negl. Trop. Dis. 2015, 9, e0003452. [CrossRef] [PubMed]

22. Aung, P.T.Z.; Cuningham, W.; Hwang, K.; Andrews, R.M.; Carapetis, J.R.; Kearns, T.; Clucas, D.; McVernon, J.; Simpson, J.A.; Tong, S.Y.C.; et al. Scabies and risk of skin sores in remote Australian Aboriginal communities: A self-controlled case series study. PLoS Negl. Trop. Dis. 2018, 12, e0006668. [CrossRef] [PubMed]

23. World Health Organization. Report of the Tenth Meeting of the WHO Strategic and Technical Advisory Group for Neglected Tropical Diseases. 2018. Available online: http:/ /www.who.int/neglected_diseases / NTD_STAG_report_2017.pdf?ua=1 (accessed on 17 March 2018).

24. World Health Organization. 9th NTD-STAG Global Working Group Meeting on Monitoring and Evaluation of Neglected Tropical Diseases. 2018. Available online: http:/ /www.who.int/neglected_diseases/events/ STAG_Working_Group_on_Monitoring_Evaluation/en/ (accessed on 12 August 2018).

25. Engelman, D.; Kiang, K.; Chosidow, O.; McCarthy, J.; Fuller, C.; Lammie, P.; Hay, R.; Steer, A. Members of the International Alliance for The Control of Scabies. Toward the global control of human scabies: Introducing the International Alliance for the Control of Scabies. PLoS Negl. Trop. Dis. 2013, 7, e2167. [CrossRef] [PubMed]

26. Engelman, D.; Fuller, L.C.; Steer, A.C. Consensus criteria for the diagnosis of scabies: A Delphi study of international experts. PLoS Negl. Trop. Dis. 2018, 12, e0006549. [CrossRef] [PubMed]

27. Taplin, D.; Porcelain, S.L.; Meinking, T.L.; Athey, R.L.; Chen, J.A.; Castillero, P.M.; Sanchez, R. Community control of scabies: A model based on use of permethrin cream. Lancet 1991, 337, 1016-1018. [CrossRef] 
28. Taplin, D.; Arrue, C.; Walker, J.; Roth, W.; Rivera, A. Eradication of scabies with a single treatment schedule. J. Am. Acad. Dermatol. 1983, 9, 546-550. [CrossRef]

29. Lawrence, G.; Leafasia, J.; Sheridan, J.; Hills, S.; Wate, J.; Wate, C.; Montgomery, J.; Pandeya, N.; Purdie, D. Control of scabies, skin sores and haematuria in children in the Solomon Islands: Another role for ivermectin. Bull. World Health Organ. 2005, 83, 34-42. [PubMed]

30. Leppard, B.; Naburi, A.E. The use of ivermectin in controlling an outbreak of scabies in a prison. Br. J. Dermatol. 2000, 143, 520-523. [CrossRef] [PubMed]

31. Pacque, M.; Munoz, B.; Greene, B.M.; White, A.T.; Dukuly, Z.; Taylor, H.R. Safety of and compliance with community-based ivermectin therapy. Lancet 1990, 335, 1377-1380. [CrossRef]

32. Pacque, M.C.; Dukuly, Z.; Greene, B.M.; Munoz, B.; Keyvan-Larijani, E.; Williams, P.N.; Taylor, H.R. Community-based treatment of onchocerciasis with ivermectin: Acceptability and early adverse reactions. Bull. World Health Organ. 1989, 67, 721-730. [PubMed]

33. Marks, M.; Taotao-Wini, B.; Satorara, L.; Engelman, D.; Nasi, T.; Mabey, D.C.; Steer, A.C. Long term control of scabies fifteen years after an intensive treatment programme. PLoS Negl. Trop. Dis. 2015, 9, e0004246. [CrossRef] [PubMed]

34. Andrews, R.M.; Kearns, T.; Connors, C.; Parker, C.; Carville, K.; Currie, B.J.; Carapetis, J.R. A regional initiative to reduce skin infections amongst aboriginal children living in remote communities of the Northern Territory, Australia. PLoS Negl. Trop. Dis. 2009, 3, e554. [CrossRef] [PubMed]

35. La Vincente, S.; Kearns, T.; Connors, C.; Cameron, S.; Carapetis, J.; Andrews, R. Community management of endemic scabies in remote aboriginal communities of northern Australia: Low treatment uptake and high ongoing acquisition. PLoS Negl. Trop. Dis. 2009, 3, e444. [CrossRef] [PubMed]

36. Romani, L.; Marks, M.; Sokana, O.; Nasi, T.; Kamoriki, B.; Wand, H.; Whitfeld, M.; Engelman, D.; Solomon, A.W.; Steer, A.C.; et al. Feasibility and safety of mass drug co-administration with azithromycin and ivermectin for the control of neglected tropical diseases: A single-arm intervention trial. Lancet Glob. Health 2018, in press.

37. Marks, M.; Toloka, H.; Baker, C.; Kositz, C.; Asugeni, J.; Puiahi, E.; Asugeni, R.; Azzopardi, K.; Diau, J.; Kaldor, J.M.; et al. Randomised trial of community treatment with azithromycin and ivermectin mass drug administration for control of scabies and impetigo. Clin. Infect. Dis. 2018, in press. [CrossRef] [PubMed]

38. Engelman, D.; Martin, D.L.; Hay, R.J.; Chosidow, O.; McCarthy, J.S.; Fuller, L.C.; Steer, A.C. Opportunities to investigate the effects of ivermectin mass drug administration on scabies. Parasit Vectors 2013, 6, 106. [CrossRef] [PubMed]

39. Mohammed, K.A.; Deb, R.M.; Stanton, M.C.; Molyneux, D.H. Soil transmitted helminths and scabies in Zanzibar, Tanzania following mass drug administration for lymphatic filariasis-A rapid assessment methodology to assess impact. Parasit Vectors 2012, 5, 299. [CrossRef] [PubMed]

40. Martin, D.; Wiegand, R.; Goodhew, B.; Lammie, P.; Mkocha, H.; Kasubi, M. Impact of ivermectin mass drug administration for lymphatic filariasis on scabies in eight villages in Kongwa District, Tanzania. Am. J. Trop. Med. Hyg. 2018, in press. [CrossRef] [PubMed]

41. Cassell, J.A.; Middleton, J.; Nalabanda, A.; Lanza, S.; Head, M.G.; Bostock, J.; Hewitt, K.; Jones, C.I.; Darley, C.; Karir, S.; et al. Scabies outbreaks in ten care homes for elderly people: A prospective study of clinical features, epidemiology, and treatment outcomes. Lancet Infect. Dis. 2018, 18, 894-902. [CrossRef]

42. Agrawal, S.; Puthia, A.; Kotwal, A.; Tilak, R.; Kunte, R.; Kushwaha, A.S. Mass scabies management in an orphanage of rural community: An experience. Med. J. Armed Forces India 2012, 68, 403-406. [CrossRef] [PubMed]

43. Beeres, D.T.; Ravensbergen, S.J.; Heidema, A.; Cornish, D.; Vonk, M.; Wijnholds, L.D.; Hendriks, J.J.H.; Kleinnijenhuis, J.; Omansen, T.F.; Stienstra, Y. Efficacy of ivermectin mass-drug administration to control scabies in asylum seekers in the Netherlands: A retrospective cohort study between January 2014-March 2016. PLoS Negl. Trop. Dis. 2018, 12, e0006401. [CrossRef] [PubMed]

44. White, L.C.; Lanza, S.; Middleton, J.; Hewitt, K.; Freire-Moran, L.; Edge, C.; Nicholls, M.; Rajan-Iyer, J.; Cassell, J.A. The management of scabies outbreaks in residential care facilities for the elderly in England: A review of current health protection guidelines. Epidemiol. Infect. 2016, 144, 3121-3130. [CrossRef] [PubMed]

45. Hewitt, K.A.; Nalabanda, A.; Cassell, J.A. Scabies outbreaks in residential care homes: Factors associated with late recognition, burden and impact. A mixed methods study in England. Epidemiol. Infect. 2015, 143, 1542-1551. [CrossRef] [PubMed] 
46. Mounsey, K.E.; Murray, H.C.; King, M.; Oprescu, F. Retrospective analysis of institutional scabies outbreaks from 1984 to 2013: Lessons learned and moving forward. Epidemiol. Infect. 2016, 144, 2462-2471. [CrossRef] [PubMed]

47. WHO Africa. Ethiopia-Scabies Outbreak Response in Amhara Regional State. Available online: https:/ / www.afro.who.int/news/ethiopia-scabies-outbreak-response-amhara-regional-state (accessed on 6 July 2018).

48. Currie, B.J.; McCarthy, J.S. Permethrin and ivermectin for scabies. New Engl. J. Med. 2010, 362, 717-725. [CrossRef] [PubMed]

49. Stolk, W.A.; Walker, M.; Coffeng, L.E.; Basanez, M.G.; de Vlas, S.J. Required duration of mass ivermectin treatment for onchocerciasis elimination in Africa: A comparative modelling analysis. Parasit Vectors 2015, 8, 552. [CrossRef] [PubMed]

50. Irvine, M.A.; Stolk, W.A.; Smith, M.E.; Subramanian, S.; Singh, B.K.; Weil, G.J.; Michael, E.; Hollingsworth, T.D. Effectiveness of a triple-drug regimen for global elimination of lymphatic filariasis: A modelling study. Lancet Infect. Dis. 2017, 17, 451-458. [CrossRef]

51. Lydeamore, M.J.; Campbell, P.T.; Regan, D.G.; Tong, S.Y.C.; Andrews, R.M.; Steer, A.C.; Romani, L.; Kaldor, J.M.; McVernon, J.; McCaw, J.M. A biological model of scabies infection dynamics and treatment informs mass drug administration strategies to increase the likelihood of elimination. Math. Biosci. 2018, in press. [CrossRef] [PubMed]

52. Wilkins, A.L.; Steer, A.C.; Cranswick, N.; Gwee, A. Is it safe to use ivermectin in children less than five years of age and weighing less than $15 \mathrm{~kg}$ ? Arch. Dis. Child 2018, 103, 514-519. [CrossRef] [PubMed]

53. Gyapong, J.O.; Chinbuah, M.A.; Gyapong, M. Inadvertent exposure of pregnant women to ivermectin and albendazole during mass drug administration for lymphatic filariasis. Trop. Med. Int. Health 2003, 8, 1093-1101. [CrossRef] [PubMed]

54. Walton, S.F.; Currie, B.J. Problems in diagnosing scabies, a global disease in human and animal populations. Am. Soc. Rev. 2007, 20, 268-279. [CrossRef] [PubMed]

55. Peeling, R.W.; Boeras, D.I.; Nkengasong, J. Re-imagining the future of diagnosis of neglected tropical diseases. Comput. Struct. Biotechnol. J. 2017, 15, 271-274. [CrossRef] [PubMed]

56. Mitjà, O.; Marks, M.; Bertran, L.; Kollie, K.; Argaw, D.; Fahal, A.; Fitzpatrick, C.; Fuller, C.; Garcia-Izquierdo, B.; Hay, R.; et al. Integrated control and management of neglected tropical diseases. PLoS Negl. Trop. Dis. 2017, 11, e0005136. [CrossRef] [PubMed]

57. World Health Organization. Recognizing Neglected Tropical Diseases through Changes on the Skin: A Training Guide for Front-Line Health Workers. 2018. Available online: http://apps.who.int/iris/ bitstream/handle/10665/272723/9789241513531-eng.pdf (accessed on 12 August 2018).

58. Estrada, R.; Chavez-Lopez, G.; Estrada-Chavez, G.; Paredes-Solis, S. Specialized dermatological care for marginalized populations and education at the primary care level: Is community dermatology a feasible proposal? Int. J. Dermatol. 2012, 51, 1345-1350. [CrossRef] [PubMed]

59. Hay, R.; Estrada, R.; Grossmann, H. Managing skin disease in resource-poor environments-the role of community-oriented training and control programs. Int. J. Dermatol. 2011, 50, 558-563. [CrossRef] [PubMed]

60. Faye, O.; Bagayoko, C.; Dicko, A.; Cissé, L.; Berthé, S.; Traoré, B.; Fofana, Y.; Niang, M.; Traoré, S.; Karabinta, Y.; et al. A teledermatology pilot programme for the management of skin diseases in primary health care centres: Experiences from a resource-limited country (Mali, West Africa). Trop. Med. Infect. Dis. 2018, 3, 88. [CrossRef]

61. Currie, B.J.; Harumal, P.; McKinnon, M.; Walton, S.F. First documentation of in vivo and in vitro ivermectin resistance in Sarcoptes scabiei. Clin. Infect. Dis. 2004, 39, e8-e12. [CrossRef] [PubMed]

62. Mounsey, K.E.; Holt, D.C.; McCarthy, J.; Currie, B.J.; Walton, S.F. Scabies: Molecular perspectives and therapeutic implications in the face of emerging drug resistance. Future Microbiol. 2008, 3, 57-66. [CrossRef] [PubMed]

63. McNair, C.M. Ectoparasites of medical and veterinary importance: Drug resistance and the need for alternative control methods. J. Pharm Pharmacol. 2015, 67, 351-363. [CrossRef] [PubMed]

64. Khalil, S.; Abbas, O.; Kibbi, A.G.; Kurban, M. Scabies in the age of increasing drug resistance. PLoS Negl. Trop. Dis. 2017, 11, e0005920. [CrossRef] [PubMed] 
65. Opoku, N.O.; Bakajika, D.K.; Kanza, E.M.; Howard, H.; Mambandu, G.L.; Nyathirombo, A.; Nigo, M.M.; Kasonia, K.; Masembe, S.L.; Mumbere, M.; et al. Single dose moxidectin versus ivermectin for Onchocerca volvulus infection in Ghana, Liberia, and the Democratic Republic of the Congo: A randomised, controlled, double-blind phase 3 trial. Lancet 2018, in press. [CrossRef]

66. Cotreau, M.M.; Warren, S.; Ryan, J.L.; Fleckenstein, L.; Vanapalli, S.R.; Brown, K.R.; Rock, D.; Chen, C.Y.; Schwertschlag, U.S. The antiparasitic moxidectin: Safety, tolerability, and pharmacokinetics in humans. J. Clin. Pharmacol. 2003, 43, 1108-1115. [CrossRef] [PubMed]

67. Mounsey, K.E.; Bernigaud, C.; Chosidow, O.; McCarthy, J.S. Prospects for moxidectin as a new oral treatment for human scabies. PLoS Negl. Trop. Dis. 2016, 10, e0004389. [CrossRef] [PubMed]

68. Bernigaud, C.; Fang, F.; Fischer, K.; Lespine, A.; Aho, L.; Dreau, D.; Kelly, A.; Sutra, J.F.; Moreau, F.; Lilin, T.; et al. Preclinical study of single-dose moxidectin, a new oral treatment for scabies: Efficacy, safety, and pharmacokinetics compared to two-dose ivermectin in a porcine model. PLoS Negl. Trop. Dis. 2016, 10, e0005030. [CrossRef] [PubMed]

69. Medicines Development for Global Health. Moxidectin Program. 2018. Available online: https://www. medicinesdevelopment.com/development-programs.htm (accessed on 3 August 2018).

70. Thomas, J.; Christenson, J.K.; Walker, E.; Baby, K.E.; Peterson, G.M. Scabies - An ancient itch that is still rampant today. J. Clin. Pharm. Ther. 2017, 42, 793-799. [CrossRef] [PubMed]

71. Engelman, D.; Fuller, L.C.; Solomon, A.W.; McCarthy, J.S.; Hay, R.J.; Lammie, P.J.; Steer, A.C. Opportunities for integrated control of neglected tropical diseases that affect the skin. Trends Parasitol. 2016, 32, 843-854. [CrossRef] [PubMed]

72. Hay, R. Skin NTDs: An opportunity for integrated care. Trans. Royal Soc. Trop. Med. Hyg. 2016, 110, 679-680. [CrossRef] [PubMed]

73. Yotsu, R.R.; Kouadio, K.; Vagamon, B.; N'Guessan, K.; Akpa, A.J.; Yao, A.; Ake, J.; Abbet, R.; Tchamba Agbor Agbor, B.; Bedimo, R.; et al. Skin disease prevalence study in schoolchildren in rural Cote d'Ivoire: Implications for integration of neglected skin diseases (skin NTDs). PLoS Negl. Trop. Dis. 2018, 12, e0006489. [CrossRef] [PubMed]

74. Thomsen, E.K.; Sanuku, N.; Baea, M.; Satofan, S.; Maki, E.; Lombore, B.; Schmidt, M.S.; Siba, P.M.; Weil, G.J.; Kazura, J.W.; et al. Efficacy, safety, and pharmacokinetics of coadministered diethylcarbamazine, albendazole, and ivermectin for treatment of bancroftian filariasis. Clin. Infect. Dis. 2016, 62, 334-341. [CrossRef] [PubMed]

75. Fischer, P.U.; King, C.L.; Jacobson, J.A.; Weil, G.J. Potential value of triple drug therapy with ivermectin, diethylcarbamazine, and albendazole (IDA) to accelerate elimination of lymphatic filariasis and onchocerciasis in Africa. PLoS Negl. Trop. Dis. 2017, 11, e0005163. [CrossRef] [PubMed]

76. Fitzpatrick, C.; Engels, D. Leaving no one behind: A neglected tropical disease indicator and tracers for the Sustainable Development Goals. Int. Health 2016, 8, i15-i18. [CrossRef] [PubMed] 